\title{
Student teachers' perceptions of democracy in the mathematics classroom: Freedom, equality and dialogue
}

\author{
Author: \\ Wajeeh Daher ${ }^{1,2}$ \\ Affiliations: \\ ${ }^{1}$ Department of Educational \\ Sciences, An-Najah National \\ University, Palestine \\ ${ }^{2}$ Department of Mathematics \\ Education, Al-Qasemi \\ Academic College of \\ Education, Israel

\section{Correspondence to:} \\ Wajeeh Daher \\ Email: \\ wajeehdaher@gmail.com \\ Postal address: \\ PO Box 8861, Nazareth \\ 16000 , Israel \\ Dates: \\ Received: 09 Feb. 2012 \\ Accepted: 16 Nov. 2012 \\ Published: 10 Dec. 2012 \\ How to cite this article: \\ Daher, W. (2012). Student \\ teachers' perceptions \\ of democracy in the \\ mathematics classroom: \\ Freedom, equality and \\ dialogue. Pythagoras, \\ 33(2), Art. \#158, 11 pages. \\ http://dx.doi.org/10.4102/ \\ pythagoras.v33i2.158
}

(C) 2012. The Authors. Licensee: AOSIS OpenJournals. This work is licensed under the Creative Commons Attribution License.
This article studies student teachers' perceptions of the pedagogic and didactic aspects of teaching and learning mathematics in a democratic classroom. It is concerned primarily with issues of democracy in the mathematics classroom, specifically freedom, equality and dialogue. The research was conducted in two mathematics teacher education classes, where students were in their third year of study to major in mathematics. To find these students' perceptions of democracy in the mathematics classroom the first two stages of the constant comparison method were followed to arrive at categories of democratic and undemocratic acts. The participants in the research emphasised that instructors should refrain from giving some students more time or opportunities to express themselves or act in the mathematics classroom than other students, because this would make them feel unequal and possibly make them unwilling to participate further in the mathematics classroom. The participants also emphasised that instructors should not exert their power to stop the flow of students' actions in the mathematics classroom, because this would trouble them and make them lose control of their actions. Further, the participants mentioned that instructors would do better to connect to students' ways of doing mathematics, especially of defining mathematical terms, so that students appreciate the correct ways of doing mathematics and defining its terms.

\section{Introduction}

Cristillo (2009) found that Palestinian universities continue to emphasise teacher-centred teaching approaches and assessment in spite of faculty exposure to student-centred approaches and the increased use of information technology by students. Similar findings are found in other reports, for example World Bank (2008), which describes educational reform in the Middle East and North Africa. To summarise this situation, the report (p. 88) says that there is little evidence of a significant shift in educational practices away from a traditional model of pedagogy, in which, despite pedagogical reforms characterised by student-centred learning, competency-based curricula and focus on critical thinking, the main student activities in classrooms continue to be copying from the blackboard, writing and listening to the teachers. This educational scene should be seen in light of the fact that Palestinian university campuses are places where students experience democratic politics, an experience which is transferred to society at large (Abu Lughod, 2000). This fact prompted Cristillo (2010) to suggest practices of student-centred classrooms, in which discussion, debate, collaborative problem solving and critical thinking prevail, as practices that contribute to Palestine's success in local, regional and global economies, as well as in the training of student teachers for democratic politics. The above situation emphasises the importance of and need to emphasise democratic issues in Palestinian university settings in general and particularly in mathematics pedagogic training courses in Palestinian universities, as well as the importance of analysing student teachers' perceptions as a consequence of this emphasis. This is also emphasised by Bailey and Murray (2009), who cite reports from the Palestinian Ministry of Education and Higher Education, UNESCO and the World Bank to conclude that higher education institutions in Palestine do not train pre-service teachers in an adequate way, and that this training does not suit the specific demands of the Palestinian education system. It is our conviction that educating future teachers to respect democratic teaching will help to change positively the educational scene in Palestinian schools, and as a result the Palestinian people, especially in the time of occupation.

The current research examines mathematics student teachers' perceptions of (un)democratic acts in the mathematics classroom after they treat this issue in the context of their pedagogic training course. Specifically, it focuses on the students' perceptions of freedom, equality and dialogue.

\section{Literature review}

In this review we will consider the educational constructs with which this research is concerned: democratic education, teachers' perceptions and pedagogic versus didactic aspects of teaching. 


\section{Democratic education}

Issues of democracy in the mathematics classroom have drawn the attention of researchers for at least three decades, during which time different aspects of these issues have been studied:

- the right to equal access to mathematical ideas (Allen, 2011; Ellis \& Malloy, 2009; Moses \& Cobb, 2001)

- authority in the mathematics classroom (Amit \& Fried, 2005; Povey, 1997; Skemp, 1979)

- promoting equality in the mathematics classroom (Croom, 1997)

- promoting democracy in the mathematics classroom (Allen, 2011; Ellis \& Malloy, 2009)

- diversity of curriculum and classroom (Ellis \& Malloy, 2009)

- revisiting old ideas in new ways (Ellis \& Malloy, 2009)

- dialogue in the classroom (Ball, Goffney \& Bass, 2005; Hannaford, 1998; Skovsmose, 1998)

- proving in the mathematics classroom (Almeida, 2010; Skovsmose, 1998)

- engaging in ethnomathematics (Ball et al., 2005; Skovsmose, 1998)

- controlling the flow of discourse (Barner, 1998; Zhang, 2005).

These different issues related to democracy in the mathematics classroom are described in more detail below. Firstly, the general issues are described, where these issues could be related to various democratic classroom topics. Secondly, the democratic issues that are of particular interest in this research are described: freedom, equality and dialogue.

Two issues that were studied regarding promoting democracy in the mathematics classroom are the beliefs of the educational agents that influence students' learning and the qualities that encourage democratic practices in the classroom. Allen (2011) says that promoting democracy in the mathematics classroom of the 21st century involves different agents (teachers, students, administrators and parents) who should hold the following beliefs as a condition for this promotion:

- all students are capable of learning powerful mathematics

- mathematics was and is still invented by humans

- students can and should help to design their mathematical learning experiences

- thinking mathematically means solving problems to which we do not know the answer

- successful education requires meaningful relationships between students and teachers.

Ellis and Malloy (2009) say that the literature on democratic education identifies the following qualities as encouraging a democratic classroom:

- A problem solving curriculum, in which the problems are related to students' lives and society, and where students have access to information that helps them to solve the problems in diverse ways.

- Inclusivity and rights: students should have access to mathematical ideas from multiple perspectives and have diverse experiences and approaches in solving problems.

- Equal participation in decisions, which are arrived at as a result of open, persuasive and negotiable discussions of mathematical and social issues and ideas. These discussions help students to create, clarify, and re-evaluate their own ideas and understand the ideas of others.

- Equal encouragement for success through encouraging the development of habits of drawing conclusions and critically evaluating implications from mathematical data for personal and social action.

Ellis and Malloy (2009) also elaborate on diversity in the mathematics classroom, considering democratic education a process of collaborative reconstruction of a curriculum that is inclusive of diversity on the part of both the teacher and the students. Such diversity is exemplified in, amongst other things, the ways in which mathematics is taught and learned. Diversity exists not only inside the classroom, but also between different classrooms based on the needs, preferences and experiences of the students and teacher.

Relating mathematical problems to students' lives is a matter of engaging students in ethnomathematics activities. Skovsmose (1998) described ethnomathematics as the study of mathematics presented in many forms in 'traditional' societies, in society routines, techniques and handicrafts, and in all kinds of ordinary life. Further, Ball et al. (2005) say that teachers should design contexts that are rooted in the broader and more diverse experiences and cultures of their students, as well as in other cultures. This, they say, is 'crucial for developing the understanding and appreciation of diverse traditions, values, and contributions' (p. 4). Such understanding and appreciation of diverse traditions, values and contributions are expected to help to maintain democratic social values and practices.

The diversity in the mathematics classroom described above can be related to freedom in the classroom. This is emphasised by the Australian-proposed charter of academic freedoms, as reported by Gelber (2009), which mandates that students be provided with diverse scholarly viewpoints. In other words, the charter considers diversity of viewpoints as a prerequisite for encouraging freedom in the classroom. Freedom in the mathematics classroom is also related to encouraging students to explore mathematical ideas (Sgroi, 1995) and the freedom to start with the easiest questions when given a classroom task (Susuwele-Banda, 2005).

Two issues that were studied regarding the right to equal access to mathematical ideas are how access to mathematical ideas (1) influences students' behaviour as citizens in a democratic society and (2) is influenced by societal perceptions and practices. Moses and Cobb (2001) argue that access to mathematics, especially algebra and advanced mathematics, is a civil right as important as the right to vote, that is, they argue that access to mathematics is a very important democratic principle. Citing examples from the literature, Ellis and Malloy (2009) describe societal 
perceptions and practices that are not democratic and which cause students not to have equal access to mathematical ideas: perceptions of ability by the teacher and society, cultural discontinuity in learning and instruction, tracking, poverty and school finance, and low expectations from teachers, parents or society.

Regarding promoting equality in the mathematics classroom, Croom (1997) mentions the following practices:

- Accommodating the learning styles of culturally diverse students.

- Organising development activities that enhance teachers' knowledge of different mathematical world views and cultural perspectives.

- Ensuring that minority and female students have an equal opportunity to learn substantive mathematics.

- Promoting the achievement of limited-language-proficiency students.

- Devising strategies that form partnerships with families.

- Affirming the richness and strength of cultural diversity.

It could be claimed that Croom's suggested practices to promote equality in the mathematics classroom are primarily cultural and social, and fit a community that consists largely of immigrants or of culturally diverse students.

Other researchers talk about the relation of mathematics to maintaining a democratic society: the theme of authority is one of the features of mathematics and is related to equality. Some researchers describe how the use of mathematics helps to achieve authority, for example Porter (1995, as reported in Wagner \& Herbel-Eisenmann, 2011) points out that bureaucrats in democracies obscure their authority by mathematical means, quantifying them without seeming to make decisions. Wagner and Herbel-Eisenmann (2011) cite such political practices to argue that promoting authority for students makes the teaching and learning of mathematics an essential condition to give students power in society.

Dialogue is an important practice in the mathematics classroom. Ball et al. (2005) say that teachers should listen closely to students' ideas; Skovsmose (1998) elaborates more on this issue, stating that '[i]t is important to make possible an interaction in the classroom which supports dialogue and negotiation' (p. 200), in order to maintain democracy in the mathematics classroom.

Some researchers relate dialogue practices in the mathematics classroom to the students' proving processes. Almeida (2010) regards proving actions in the classroom as having a democratic flavour when they are accompanied by interrogation, convincing and agreement actions. Almeida emphasises that teachers' explanatory arguments should be open to students' scrutiny and debate and, at the same time, pupils' sense of argumentation, reasoning and reasonableness should be regarded as legitimate. Skovsmose (1998) also emphasises the importance of respecting students' sense of argumentation, saying that the teacher 'should be aware of the student's good reasons in order to escape the paradigm of classroom absolutism' (p. 200).
Dialogue is also related to the equality and authority issue in terms of controlling the flow of discourse. Zhang (2005) considers this control a symptom of exerting power in a discourse. In fact, Zhang considers power a relationship with the others in a discursive practice. This consideration can be used as a tool for analysing power in the mathematics classroom dialogue: where, in a traditional classroom, the teacher controls the discourse and thus the power, in the collaborative classroom, the power is distributed amongst the students too, with some at times having more power than others. Zhang further mentions mathematics knowledge, social assignation, gender, class, race, and religion as factors that influence an individual's power in the mathematics classroom. Barner (1998) mentions various ways in which students act to control or influence the flow of group discourse, and thus exert power on the group activity: initiating a negotiating event, initiating off-task talk, and rejecting or ignoring off-task talk by continuing the negotiating event or by initiating a new one.

Dialogue is not only related to equality and authority in the mathematics classroom, but also to freedom. For example, Geoghegan, Petriwskyj, Bower and Geoghegan (2003) argue that to foster children's ability to express unique ideas teachers need to allow them some freedom to move in the classroom with autonomous flexibility and to interact with their peers in informal ways.

The above descriptions of the various democratic issues in the mathematics classroom not only highlight the uniqueness of each issue, but also their inter-dependence: the realisation of one assures or leads to the realisation of the others.

\section{Perceptions of teachers}

Teacher's perceptions are an important element that influence the teacher's teaching method and their behaviour in the classroom. This means teachers' perceptions are an element that influences students' learning as well. Research shows what the impact of teachers' perceptions, expectations and opinions on their behaviour in the classroom and on their students' learning can be. Trouilloud, Sarrazin, Martinek and Guillet (2002), for example, report that students' achievements validated their teacher's expectations of them. Several researchers have examined the influence of perceptions on behaviour, saying that one's perceptions of the self and the reality in which one lives influence one's behaviour. Perceptions are not a passive process of absorption of facts and impressions, but a compound and active process which is influenced by various variables, such as past experiences, expectations and emotions, which design our perception's domain (Bar-Al \& Noymeyer, 1996). Chanal, Sarrazin, Guay and Boiché (2009) say that the theories concerned with perceptions of the self suggest that perceptions students have about their ability in a specific subject are not side effects, but an important cognitive state that influences students' behaviour and academic achievement. This importance of the students' perceptions explains why it is necessary to examine student teachers' perception of democratic acts in 
the mathematics classroom, so as to evaluate their future teaching practices in the classroom and examine how they prepare their students for democratic life, and independent and critical thinking.

\section{Pedagogy and didactics}

Two educational aspects with which this research is concerned are pedagogy and didactics. Andrews (2007) differentiates between the two by saying that pedagogy is concerned with the curriculum in both broad and narrow forms, and the underlying systemic aims and objectives of education. In addition, pedagogy transcends subject boundaries and acknowledges general theories of teaching and learning. For Andrews, pedagogy includes didactics, which is concerned with the strategies and warranted approaches to subject teaching and learning. These strategies and approaches may vary from one subject to another. In addition, didactics acknowledges theories of teaching and learning but from the subject-specific perspective. Shulman (1987) described pedagogic knowledge as the knowledge of pedagogic principles and techniques that are concerned with efficient teaching, and which is not concerned with a specific subject. Shulman described pedagogic content knowledge as the knowledge of the teaching methods of a specific subject. In the current research we will treat the pedagogic and didactic aspects of democratic acts in a mathematics pedagogic training course in these terms, where the didactic aspect is the pedagogic content knowledge, according to Shulman. These two aspects should be attended to in the mathematics classroom, in which each complements the other in general and as regards democracy in particular. The didactic aspect is not largely attended to in the literature on democracy in the mathematics classroom.

\section{Pedagogic aspects of democracy in the mathematics classroom versus didactic issues}

Some of the previous issues and sub-issues regarding democracy in the mathematics classroom can be related to the political aspect of teaching and learning mathematics, whilst others can be related to the cultural, social, pedagogic and didactic aspects of teaching and learning mathematics. For example, some sub-issues of the right to equal access to mathematical ideas can relate to the political aspect, such as poverty and school finance; the sub-issues of societal perceptions of ability, cultural discontinuity in learning and instruction can relate to the pedagogic aspect of teaching and learning. On the other hand, the equality sub-issue of devising strategies that form partnerships with families can relate to the social aspect of learning and teaching mathematics in the mathematics classrooms; the sub-issue of affirming the richness and strength of cultural diversity can relate to the cultural aspect. Regarding the didactic aspect of teaching and learning mathematics, the problem-solving curriculum sub-issue of relating problems to students' lives and society can relate to the didactic aspect of teaching and learning mathematics because this sub-issue influences teachers' methods of teaching mathematics. The current research is concerned with both the pedagogic and the didactic issues of teaching mathematics so can be considered to embrace a continuum of researches in these two fields.

\section{The research framework}

This research focuses on the pedagogic and didactic aspects of teaching and learning mathematics in a democratic classroom. It is concerned primarily with some of the previously described issues of democracy in the mathematics classroom, specifically freedom, equality and dialogue. These issues are important issues of democracy as well as of teaching and learning mathematics (Alrø \& JohnsenHøines, 2010; Alrø \& Skovsmose, 2002; National Council of Teachers of Mathematics [NCTM], 2000; Vithal, 2000a, 2000b; Wilson \& Lloyd, 1996). Freedom can be viewed as the freedom to choose and act as a means to control learning and equality as 'the fair and equal distribution of mathematical knowledge and other educational opportunities for all members of society' (Vithal, 1999, p. 27). Dialogue is viewed as the verbal interactions amongst learners and between them and their teacher; this interaction could be about their experience of learning and about forms of classroom practice (Boylan, 2009).

Various researchers have been involved with democracy in the mathematics classrooms, but most of these were concerned with global pedagogic issues, for example providing equal access and attainment for all students (Allen, 2011). The current research attempts to examine complementary issues: pedagogic and didactic issues of democracy inside the mathematics classroom, significantly concerned with the pedagogic and didactic issues of teaching and learning mathematics. The current research sheds light on the pedagogic and didactic democratic acts in the mathematics classroom, as perceived by student mathematics teachers. This will direct student teachers and teacher educators to the methods and behaviours that encourage democracy in the mathematics classroom and, as a result, encourage constructivist and social constructivist teaching and active learning of mathematics.

The research question being addressed is: What pedagogic and didactic acts do student mathematics teachers perceive as democratic in a mathematics classroom (a university pedagogic training classroom)? More specifically, what pedagogic and didactic acts do student mathematics teachers perceive as:

1. promoting or lessening freedom

2. promoting equality or inequality

3. encouraging or discouraging dialogue in a mathematics classroom?

\section{Methodology The research setting and participants}

The research was conducted in two mathematics pedagogic training classes at a large university in Palestine. The student teachers were in their third year of study, majoring in 
mathematics. One class was held in the second semester of the 2010-2011 academic year and the second class was held in the second semester of the 2011-2012 academic year. The first class included 26 student teachers; the second included 41 student teachers. The mean age of the participants was 21.4 years with a standard deviation of 1.2. The mathematics pedagogic training course addressed various issues of teaching mathematics in the classroom, including the issue of democracy, which was raised near the end of the course. The assignments in the course included exams, a reflective portfolio, preparing a unit of three or more lessons on a mathematical topic and microteaching in front of the class. The microteaching was assigned from the beginning of the semester, 15-20 minutes for each student. The instructor had two strategies: interfering during the microteaching if there was a critical remark to give, for example correcting a wrong mathematical definition that the student who did the microteaching gave, and discussing the microteaching with the whole class at the end of the microteaching session. The portfolio included writing reflections on the course's lectures, on the school training and any other mathematics related work.

\section{Data production and analysis}

At the end of each course, the student teachers were asked to give their evaluation of the course outline with respect to the democratic aspects of freedom, equality and dialogue. They had to write down six acts which occurred or were discussed during the course: one that supported freedom, one that hindered freedom, one that promoted equality, one that hindered equality, one that promoted dialogue and one that hindered dialogue.

The participants' evaluations of the democratic or undemocratic aspects of the pedagogic training course constituted the data in this research. In order to evaluate the democratic aspects of the course's outline, the student teachers were asked to give their evaluations on a voluntary basis. In the first class, 24 of the 26 student teachers participated; in the second class, 38 out of 41 participated.

The first two stages of the constant comparison method (Glaser \& Strauss, 1967) were followed to arrive at categories of democratic and undemocratic acts (acts that support freedom or hinder it, acts that promote equality or hinder it and acts that promote dialogue or hinder it). These stages were:

- Categorising data: putting together data expressions or sentences that imply a category of democracy, for example, putting together all expressions or sentences that imply a freedom category, for example, the freedom to express opinion.

- Comparing data: comparing expressions or sentences within each previously built category. This gave rise to sub-categories. For example, in the category 'the freedom to express opinion', comparing expressions or sentences in students' answers differentiates between expressions and sentences that imply expressing opinion and those that imply another category of freedom.
Validity and reliability of the research tools and procedure

The validity of the research analysing procedure was guaranteed by ensuring theoretical saturation by continuing the analysis of the participants' answers until (1) no new category or theme regarding freedom, equality and dialogue appeared, and (2) every category was well developed in terms of its properties and dimensions demonstrating variation (Strauss \& Corbin, 1998, p. 212).

Lincoln and Guba (1985) say that no validity exists without reliability, so the ensuring of validity also ensures reliability. This means that following theoretical saturation maintains not only the validity of the research procedure but also its reliability.

Two experienced coders (one of them the author) coded the participants' texts, searching for categories in the participants' perceptions of the three aspects of democracy in the mathematics classroom, freedom, equality and dialogue. The agreement between the coders (Cohen's Kappa coefficient) was 0.86 for freedom, 0.79 for equality and 0.85 for dialogue.

\section{Ethical considerations}

The participants were asked to give their evaluations of the pedagogic training class regarding democracy aspects on a voluntary basis. Further, they were directed not to write their names on the assignment. The goal was for them to describe anonymously and thus openly their perceptions of the democratic atmosphere in the mathematics pedagogic training classes. The participants were directed to write six incidents that occurred during the course's lectures. The goal was to make sure that the participants considered both sides of the democratic phenomenon in the classroom, and not just the positive side. These steps were performed to ensure ethical treatment of the researcher-participant relationship (Ramos, 1989).

The university gave its consent for this research to be conducted in the mathematics pedagogic training course, on the condition that the student teachers agreed to participate in it. The participating student teachers gave their permission for their answers to be available for this research and agreed that their exact sentences could be used for the research goals.

\section{Findings}

The findings on student teachers' perceptions of the three democratic issues will be presented in the following order: the freedom issue, the equality issue and the dialogue issue. For every issue, four tables will be built, describing categories related to: acts promoting the pedagogic aspect of the issue, acts lessening the pedagogic aspect of the issue, acts promoting the didactic aspect of the issue and acts hindering the didactic aspect of the issue. The pedagogic categories are related to general acts, that is, acts which could happen in any classroom and not only in the mathematics classroom. The didactic categories are related to acts that happen specifically in the mathematics classroom. 


\section{Student teachers' perceptions of freedom}

The acts described by the participants as promoting or lessening freedom in the mathematics pedagogic training course can be divided into pedagogic acts and didactic acts. These two types of acts can be further divided into subcategories. These subcategories, with appropriate examples, are described in Tables 1-4.

Table 1 shows that the participants talked primarily about three pedagogic acts that promote freedom in the classroom: the freedom to express oneself, the freedom to decide and the freedom to act. Table 2 points at the importance that the participants gave to having freedom to act and communicate. Table 3 shows that the freedom to express oneself and the freedom to decide are not only important pedagogic acts that assist students' freedom, but also didactic acts that lead to the same result: the students having learning freedom. Finally, Table 4 points to the freedom of students to ask questions as another important block of didactic acts that promote or hinder students' freedom in the mathematics classroom.

\section{Student teachers' perceptions of equality}

Categories of equality prevalence or absence are divided into subcategories with appropriate examples in Tables 5-8.

Table 5 and Table 7 show that the participants perceived the instructor-student relationship as important to pedagogic and didactic equality in the mathematics classroom. Table 8 shows that the participants were concerned with the teaching processes that influence their learning processes, particularly those processes related to the teaching methods and teacher's examples. Table 6 shows that it was important for the participants that the instructor does not perform discriminating acts between them that could be related to their achievement.

\section{Student teachers' perceptions of dialogue}

Categories of dialogue encouragement or discouragement are divided into subcategories with appropriate examples in Tables 9-12.

Table 9 shows that the participants perceived the pedagogic acts that are related to expressing oneself and students' roles as important to dialogue in the classroom. In addition, the possibility and potentiality of mathematical discussions and finished or unfinished talk also caught the attention of the participants, not only for encouraging discussions but also for discouraging them, as Table 10 and Table 12 show. Interestingly, as Table 11 shows, the prevalence of dialogue in the mathematics classroom is related to justification and use of natural language.

\section{Discussion}

\section{Pedagogic (un)democratic acts in the mathematics classroom}

The research findings, as can be seen in Table 1, show that the student teachers considered self-expression to
TABLE 1: Pedagogic acts promoting freedom.

\begin{tabular}{|c|c|}
\hline Category of act & Examples of students' comments \\
\hline $\begin{array}{l}\text { The freedom of expression: } \\
\text { - the freedom to express opinion. } \\
\text { - the freedom to express criticism. }\end{array}$ & $\begin{array}{l}\text { - The portfolio enabled us to write our } \\
\text { opinion of the lectures. } \\
\text { - We were able to criticise the instructor } \\
\text { regarding the first exam. }\end{array}$ \\
\hline The freedom to decide & $\begin{array}{l}\text { - It was important that we could decide } \\
\text { which topic we wanted to teach. }\end{array}$ \\
\hline The freedom to act & $\begin{array}{l}\text { - The instructor allowed the students to } \\
\text { use any tool in their teaching and to } \\
\text { have control of the classroom. }\end{array}$ \\
\hline
\end{tabular}

TABLE 2: Pedagogic acts lessening freedom.

\begin{tabular}{|c|c|}
\hline Category of act & Examples of students' comments \\
\hline $\begin{array}{l}\text { Limiting students' acts: } \\
\text { - hindering students' acts } \\
\text { - interrupting students' acts or } \\
\text { communication } \\
\text { - prohibiting students' acts or } \\
\text { communication } \\
\text { - putting limits or constraint on } \\
\text { students' acts. }\end{array}$ & $\begin{array}{l}\text { - The instructor obliged me to stop giving } \\
\text { my lesson. } \\
\text { - The instructor interrupted me while } \\
\text { giving my lesson and this confused me. } \\
\text { - The instructor did not allow me to } \\
\text { explain why I gave my classmates so } \\
\text { much learning materials in a short time. } \\
\text { The instructor put a limit from the } \\
\text { beginning on the time of our lesson. }\end{array}$ \\
\hline Criticising students' acts & $\begin{array}{l}\text { The instructor criticised our teaching, so } \\
\text { we did not have the freedom to teach as } \\
\text { we had already planned. }\end{array}$ \\
\hline
\end{tabular}

TABLE 3: Didactic acts promoting freedom.

\begin{tabular}{ll}
\hline Category of act & Examples of students' comments \\
\hline $\begin{array}{l}\text { The freedom of students' self-expression: } \\
\begin{array}{l}\text { - expressing didactic ideas regarding } \\
\text { the issues of the course }\end{array}\end{array}$ & $\begin{array}{l}\text { - At the beginning of the course, we } \\
\text { could suggest what the parts of a } \\
\text { mathematical lesson should be and the } \\
\text { components of each part. }\end{array}$ \\
$\begin{array}{ll}\text { describing mathematical ways. } \\
\text { The instructor gave every student the } \\
\text { opportunity to present her way of } \\
\text { solving a mathematical problem. }\end{array}$ \\
$\begin{array}{ll}\text { The freedom to decide: } \\
\text { choosing the method they want to } \\
\text { use in solving a mathematical problem. }\end{array}$ & $\begin{array}{l}\text { - Teachers in schools should give their } \\
\text { students the freedom to decide which } \\
\text { solution method they want to use in } \\
\text { order to solve a specific mathematical } \\
\text { problem. }\end{array}$ \\
\hline
\end{tabular}

TABLE 4: Didactic acts lessening freedom.

\begin{tabular}{ll}
\hline Category of act & Examples of students' comments \\
\hline $\begin{array}{l}\text { Withholding the freedom to make } \\
\text { didactic decisions from students }\end{array}$ & $\begin{array}{l}\text { - You forced us to use the guided } \\
\text { discovery teaching method to prepare } \\
\text { our unit. }\end{array}$ \\
$\begin{array}{l}\text { Withholding the freedom to ask } \\
\text { mathematical questions from students }\end{array}$ & $\begin{array}{l}\text { - Teachers should not prevent students } \\
\text { from asking questions about the new } \\
\text { mathematical topic introduced. }\end{array}$ \\
\hline
\end{tabular}

TABLE 5: Pedagogic acts promoting equality.

\begin{tabular}{|c|c|}
\hline Category of act & Examples of students' comments \\
\hline Not discriminating between the students & $\begin{array}{l}\text { - The instructor did not discriminate } \\
\text { between male and female students. } \\
\text { - The instructor did not discriminate } \\
\text { among the students in grades. }\end{array}$ \\
\hline $\begin{array}{l}\text { Instructor-students relation: } \\
\text { - the role of the students. }\end{array}$ & $\begin{array}{l}\text { - We exchanged the role with the } \\
\text { instructor, sometimes we were those } \\
\text { who presented our ideas and the } \\
\text { instructor listened. }\end{array}$ \\
\hline The instructor-student relation & $\begin{array}{l}\text { The instructor presented the information } \\
\text { as if he learnt it with us. We felt he is one } \\
\text { of us. }\end{array}$ \\
\hline
\end{tabular}

TABLE 6: Pedagogic acts promoting inequality.

\begin{tabular}{ll}
\hline Category of act & Examples of students' comments \\
\hline Discriminating acts: & $\begin{array}{l}\text { - The instructor gave some students } \\
\text { - unequal teaching time } \\
\text { - unequal discussion time. }\end{array}$ \\
$\begin{array}{l}\text { students. } \\
\text { Sometimes I felt there was inequality } \\
\text { because the instructor let the } \\
\text { outstanding students participate in } \\
\text { the discussions more than the other } \\
\text { students. }\end{array}$ \\
$\begin{array}{l}\text { There was no clear criterion for the } \\
\text { portfolio evaluation, so I felt students } \\
\text { were not evaluated equally. }\end{array}$ \\
\hline
\end{tabular}


TABLE 7: Didactic acts promoting equality.

\begin{tabular}{|c|c|}
\hline Category of act & Examples of students' comments \\
\hline $\begin{array}{l}\text { Taking care of the individual } \\
\text { differences between students: } \\
\text { - providing different solution methods. }\end{array}$ & $\begin{array}{l}\text { The instructor should give different } \\
\text { solution method, so every student } \\
\text { chooses what best suits her. This would } \\
\text { give equal learning opportunities for the } \\
\text { students. }\end{array}$ \\
\hline $\begin{array}{l}\text { Taking care of every student by: } \\
\text { - giving feedback } \\
\text { - encouraging to participate. }\end{array}$ & $\begin{array}{l}\text { - The instructor commented on every } \\
\text { mathematical lesson presented by the } \\
\text { students without exception. } \\
\text { - The instructor encouraged every } \\
\text { student to tell about their didactic } \\
\text { experiences in the training schools. }\end{array}$ \\
\hline
\end{tabular}

TABLE 8: Didactic acts promoting inequality.

\begin{tabular}{ll}
\hline Category of act & Examples of students' comments \\
\hline Diversity in: & - Teachers should not solve a \\
- teachers' methods & mathematical problem in one \\
- teachers' examples. & way because this way may not be \\
& appropriate for all students, so \\
& the students may not have equal \\
& opportunities of understanding. \\
- Teachers should not give as examples & just simple mathematical problems or \\
& just difficult ones. Teachers' examples \\
& should be directed equally to all \\
& students, taking into consideration \\
& their different levels. \\
\hline
\end{tabular}

TABLE 9: Pedagogic acts that encourage dialogue.

\begin{tabular}{|c|c|}
\hline Category of act & Examples of students' comments \\
\hline Having the opportunity to express oneself & $\begin{array}{l}\text { - We were able to tell about our } \\
\text { experiences during the lectures. }\end{array}$ \\
\hline $\begin{array}{l}\text { Discussion acts: } \\
\text { - enquiring about ideas } \\
\text { - listening to ideas } \\
\text { - building ideas. }\end{array}$ & $\begin{array}{l}\text { - The instructor always asked the } \\
\text { students the question: 'What do you } \\
\text { think?' } \\
\text { - The instructor listened to the students' } \\
\text { points of view and did not neglect any } \\
\text { student's ideas. } \\
\text { - Every idea that evolved in the class } \\
\text { underwent discussion and argument. }\end{array}$ \\
\hline The students' role & $\begin{array}{l}\text { The instructor let us suggest topics for } \\
\text { discussion, and this empowered us. }\end{array}$ \\
\hline
\end{tabular}

TABLE 10: Pedagogic acts discouraging dialogue.

\begin{tabular}{ll}
\hline Category of act & Examples of students' comments \\
\hline Incomplete discussions & $\begin{array}{l}\text { Sometimes the instructor ended a } \\
\text { discussion because he had other class } \\
\text { agenda. }\end{array}$ \\
\hline
\end{tabular}

TABLE 11: Didactic acts encouraging dialogue.

\begin{tabular}{ll}
\hline Category of act & Examples of students' comments \\
$\begin{array}{l}\text { Acts that encourage classroom dialogue } \\
\text { regarding didactic issues: }\end{array}$ & $\begin{array}{l}\text { - Letting us discuss freely issues related } \\
\text { to the teaching of mathematics made } \\
\text { our character stronger. }\end{array}$ \\
$\begin{array}{l}\text { - starting lessons with discussions } \\
\text { taking into consideration students' } \\
\text { opinions. }\end{array}$ & $\begin{array}{l}\text { The instructor asked the students to } \\
\text { discuss the best way to teach the topic } \\
\text { of solving two equations with two } \\
\text { unknowns. } \\
\text { - The instructor took our opinion } \\
\text { regarding the new teaching methods of } \\
\text { mathematics like telling stories. }\end{array}$ \\
$\begin{array}{ll}\text { The instructor did not accept any claim } \\
\text { from the students without justification. }\end{array}$ \\
$\begin{array}{l}\text { This made us more aware of what we say } \\
\text { during the class discussions. }\end{array}$ \\
$\begin{array}{l}\text { Writing the mathematical relations with } \\
\text { words on the board strengthens the } \\
\text { student because he understands the } \\
\text { relations better. }\end{array}$ \\
\hline
\end{tabular}

TABLE 12: Didactic acts discouraging dialogue.

\begin{tabular}{ll}
\hline Category of act & Examples of students' comments \\
\hline $\begin{array}{l}\text { Not connecting to students' ways of } \\
\text { doing mathematics }\end{array}$ & $\begin{array}{l}\text { The instructor did not accept our } \\
\text { ways of defining mathematical terms, } \\
\text { so I refrained sometimes from giving } \\
\text { definitions of the discussed terms. }\end{array}$ \\
$\begin{array}{ll}\text { You advised us to let the pupil finish his } \\
\text { solution method without interrupting } \\
\text { him. I agree with this advice because } \\
\text { interrupting the pupil makes him } \\
\text { refrain from participating in the class } \\
\text { discussions, and as a result in solving } \\
\text { mathematical problems. }\end{array}$ \\
\hline
\end{tabular}

be an important aspect of freedom. The rest of the aspects mentioned by the participants as acts of freedom in the mathematics classroom, the freedom to act, to decide and to criticise, indicate the importance of self-realisation, which is a required learning outcome (Isman, Altinay \& Altinay, 2004). The importance that the participants gave to self-expression as a self-realisation aspect could be due to different causes, namely, (1) the importance of students' self-realisation to their activity in the mathematics classroom, (2) the course outline, where the students were not satisfied with the freedom issues in the course, and (3) the national and political conditions of the participants, which could hinder the advancement of their self-expression and self-realisation. These findings agree with Kesici (2008) who reported that the school teachers participating in his study pointed out that teachers would better allow school students to express their ideas, which promotes their self-realisation. The participants in the current research, as Table 2 shows, also pointed out the importance of having the freedom to act and communicate, but it seems that some of them did not understand the limits of educational freedom: they considered the instructor's criticism of their microteaching as negatively influencing this teaching. The participants were new to teaching, so they were not sure of themselves as teachers, and thus considered any criticism or interruption as a threat to their teaching. Instructors should take into consideration their students' knowledge and experience and state their feedback on students' action in a way that the students accept, so that they benefit from this feedback. In addition, a dialogue should be held between the students and the instructor to discuss the role of critiquing in the democratic mathematics classroom, where this critiquing is an indicator of a healthy democratic classroom (MacMath, 2008). An alternative explanation could be that the course outline failed to convince the students of the prevalence of freedom in it, so they expressed their perception of the lack of it.

The second issue of democracy in which this research is interested is equality, which has been researched educationally from various angles; one aspect that has been researched extensively is the gender aspect (Canadian International Development Agency 2010; United States Agency for International Development [USAID], 2008). Here, as Table 5 shows, the participants were concerned with being not discriminated against because of their gender and specifically not discriminated against in their course grades. Students' role in teaching and learning, as Table 5 shows, caught the attention of the participants too as an issue related to equality in the mathematics classroom: their ability to present their experiences in the classroom made them feel equal with the instructor. The student's role in the instructorstudent relationship is considered by various researchers to be a component of democracy in the elementary and secondary classroom (see e.g. Davis, 2010; Larrivee, 2002). In this research, as Table 5 shows, the student teachers were content to exchange their role with the role of their instructor, probably because this exchange empowered them and supported their self-esteem. 
Talking about inequality in the classroom, as perceived by the participating students, USAID (2008) four types of equality in education can help us. These types are: equality of access, equality in the learning process, equality of educational outcomes and equality of external results. Here, as Table 6 shows, the participants were concerned with inequality between students in the learning process (time allocated to each of them in microteaching or discussion) and in the educational outcomes (the absence of clarity in the assignments evaluation criteria).

The third issue of democracy with which this research is concerned is the dialogue issue. The participants in this research mentioned four different communicational acts as democratic: discussing, asking, arguing and listening. These acts imply the importance of open dialogue and open discussion in the classroom in order to foster a democratic climate (Harwood \& Hahn, 1990). Further, the issue of democracy limit is of relevance here. This is about the situations in which teachers have to end an educational action in the classroom to start another for whatever reason. Sometimes, students do not understand their teacher's decision and consider it undemocratic. Morrison (2008) reminds, whilst talking about her experience with student teachers, that students may consider some classroom acts as undemocratic if they mistake positive freedom for negative freedom; in our case, the student teachers did not accept the necessity of putting an end to a classroom dialogue, probably thinking that the dialogue should continue until all issues related to it were settled. The pedagogic dialogue aspects of the mathematics classroom that the participants perceived were similar to those pointed out by other researchers. For example, Poduska (1996) says that teachers implementing a democratic pedagogy should not only encourage open dialogue, but also encourage critical student feedback on aspects of the school.

\section{Didactic (un)democratic acts in the mathematics classroom}

The participants in the research, as Table 3 shows, admired their ability to suggest at the beginning of the course what the parts of a mathematical lesson should be and the components of each part. They considered this ability a democratic act; this agrees with Allen (2011), who says that to promote democracy in the mathematics classroom students should help in designing their mathematical learning experiences. The participants, as Table 3 shows, were also concerned with problem solving and their ability to suggest and use solution methods other than those suggested by the teacher. The ability of students to suggest and use their own solution methods is emphasised in previous research as a way to advance students' mathematical thinking (Fraivillig, 2001) and improve their achievement (Grouws \& Cebulla 2000). This concern with problem solving has different aspects, freedom being just one of them, but the results imply that freedom related to problem solving in the mathematics classroom is supposed to contribute to students' learning and achievement, as well as their feeling of didactic freedom.
Previous researchers (Akinbobola \& Afolabi, 2010; Kesici, 2008) have pointed at student-centred and guided-discovery teaching methods as methods that should prevail in the democratic classroom, for they encourage learners to be autonomous and responsible (Akinbobola \& Afolabi, 2010). It seems that the students who have not practised teaching in schools were not impressed by these teaching methods, for they had not seen their practical benefits, so they took into their consideration mainly their didactic ability to act and decide. On the other hand, the participants were concerned also with the ability of the students to ask questions in the mathematics classroom, probably because asking questions allows students to verify their understanding and be more autonomous as learners and less dependent on the teacher (Anthony \& Walshaw, 2007).

To discuss the participants' perceptions of didactic equality in the mathematics classroom, let us stay within the framework of USAID's (2008) categorisation of equality types. The participants were concerned with three of these types when talking about didactic acts that promote equality in the mathematics classroom: equality of access to problem solving and solution methods; equality in the learning process, including the instructor as one of the learners; and equality in the educational outcomes that include the instructor's feedback and the students' discussion about their experiences. The findings regarding the participants' perceptions of didactic equality also agree with Kesici (2008), who pointed out that providing equality in the classroom should include both the learning process and classroom activities.

Talking about didactic acts that promote equality in the mathematics classroom, as Table 7 shows, the participants talked about the need to provide different solution methods in the democratic mathematics classroom. This agrees with Ellis and Malloy (2009) who said that students in the democratic classroom should have access to mathematical ideas from multiple perspectives and have diverse experiences and approaches in solving problems. Here, the equality is a consequence of the recommended educational environment and not a procedural one. It can be said that the participants were concerned with teaching processes that influence learning processes. The diversity of mathematics teachers' methods emphasised by the participants has also been attended to in the literature. For example, one of the principles set out by the National Council of Teachers of Mathematics (NCTM, 2000) is the Equity Principle which states that all students must have the opportunity to study and the appropriate support to learn mathematics. Moreover, Klassen (2008) suggests practical adaptations and instructional strategies that could address the diversity of students in the mathematics classroom. Here the participants suggested that teachers should implement diverse teaching methods and give diverse examples to reach all students in the mathematics classroom.

The participating student teachers, as Table 11 shows, were aware of different acts in the mathematics class that 
encourage dialogue and at the same time result in better learning: expressing oneself, inquiring about ideas, listening to ideas, building ideas and suggesting topics for discussion. These class acts point at effective communication between the teacher and the students and encourage positive learning processes (Kibler, Rush \& Sweeney, 1985). A healthy communication established between the teacher and the students not only increases students' educational success, but also allows a safe environment for them (Kohn, 1997). Thus, open class dialogues not only point at a democratic class, but also contribute to students' learning processes and outcomes.

Regarding didactic acts that do not promote dialogue in the mathematics classroom, as Table 12 shows, some participants said that by not accepting their ways of defining mathematical terms the instructor discouraged their participation in discussions about these terms. This perception made it difficult for the instructor to develop and build on students' ways of doing mathematics. Schifter (2001) says that being sensitive to students' conceptual issues is critical for building on and developing students' thinking, so it can be said that the instructor, by not connecting to the students' definitions, made them reluctant to participate in further class discussions. The teacher's interruptions of students' talk also made it difficult for the teacher to build on and develop students' thinking if the students took the interruptions to be an act of authority.

\section{Conclusions}

Allen (2011) describes the classroom where democratic mathematics education cannot take place: the students learn the same way, work toward a single best solution, minimise interaction and teamwork, and focus on the mathematical ends or answers rather than the means or processes. The participants in this research pointed at some of the opposite of these acts as didactic democratic acts, as they perceived them in the frame of a pedagogic training course. Some of these acts are related to didactic freedom in the mathematics classroom, for example encouraging students to suggest their own ways of solving mathematical problems and freedom of self-expression. Other acts are related to didactic equality in the mathematics classroom, for example allowing students to have different ways to learn new mathematical topics, so that they have equal opportunities to learn and understand mathematics. The rest of the acts are related to didactic dialogue in the mathematics classroom, for example collaborative discussions on mathematics education issues amongst students to arrive at new mathematical concepts, justification of claims and communication using natural language. The students' perceptions of democratic didactic acts, as described above, agree with Ellis and Malloy (2009) about the democratic mathematics classroom, but the participants also pointed to a need for freedom of students to suggest their own ways of solving mathematical problems, probably because this advances their mathematical thinking and achievement (Fraivillig, 2001; Grouws \& Cebulla, 2000). These acts, in addition to being democratic (Vithal, 1999, as cited in Ellis and Malloy, 2009), would result in a better environment for students' learning of mathematics (Staples \& Bartlo, 2010).

Didactic acts that the students identified as undemocratic were: freedom acts, such as withholding the freedom to decide or to ask question (see e.g. Olaye, 2008); equality acts, such as not giving diverse examples; and dialogue acts, such as not connecting to students' ways of doing mathematics, and interrupting students' work or discussions. The identification of these acts emphasises the importance and positive influence of specific practices in the classroom in general and in the mathematics classroom in particular. The results also extend the repertoire of these practices to include connecting to students' ways of doing mathematics.

Regarding pedagogic democratic acts in the mathematics classroom, the participants in the research identified the following acts as democratic: freedom acts, such as the freedom to criticise, to express opinion, to decide and to act; equality acts, such as exchanging roles with the teacher; and dialogue acts, such as exchanging ideas. These pedagogic acts, implemented in the democratic classroom, would positively influence the learning outcomes (Isman, Altinay \& Altinay, 2004). The participants identified the following pedagogic acts as undemocratic: freedom acts, such as hindering, interrupting, prohibiting, putting limits or criticising students' acts; equality acts, such as discriminating between students and performing unclear acts that obscure the equality in grade assignment; and dialogue acts, such as ending class discussions. Implementation of the mentioned democratic acts and avoidance of the undemocratic acts would not only result in a better environment for students' learning of mathematics, but they would also help to make students better citizens (Skovsmose, 1998).

The findings of the research imply that instructors should try not to give certain students more time or opportunities to express themselves or act in the mathematics classroom than other students. Such discrimination makes the other students feel unequal and possibly discourages them from further engaging in the class (Povey, 2010). The findings also suggest that instructors should not exert their power to stop the flow of students' actions in the mathematics classroom, because this troubles students and causes them to lose their control of their actions, especially when teachers' power is not perceived positively (Botas, 2004).

Instructors should try to connect to students' ways of doing mathematics, especially their ways of defining mathematical terms and giving solutions to mathematical problems, because otherwise students do not appreciate the correct ways of doing mathematics and defining its terms. Further, this connecting to students' ways of doing mathematics helps them to develop their thinking (Schifter, 2001).

Specifically within the Palestinian context, it is hoped that more emphasis will be put on democracy in classrooms, especially mathematics classrooms, where students gain a 
powerful knowledge for their future life. This emphasis will provide students with better foregrounds - interpretations and conceptualisations of their future, their possibilities, and their life conditions given the social, cultural, economic and political environment in which they live (Skovsmose \& Valero, 2005) - which, in turn, will positively influence what the students do and want to do, by providing them with resources and reasons to get involved in their learning and society as acting persons. This is especially important in Palestine, where the Israeli occupation still prevails and negatively influences the foregrounds of students.

\section{Acknowledgements \\ Competing interests}

The author declares that he has no political, cultural or personal relationships which may have inappropriately influenced him in writing this article.

\section{References}

Abu-Lughod, I. (2000). Palestinian higher education: National identity, liberation and globalization. Boundary 2, 27(1), 75-95. http://dx.doi.org/10.1215/01903659-271-75

Akinbobola, A.L., \& Afolabi, F. (2010). Constructivist practices through guided discovery approach: The effect on students' cognitive achievement in Nigerian senior secondary school physics. The Eurasian Journal of Physics and Chemistry Education, 2(1), 16-25.

Allen, K. (2011). Mathematics as thinking: A response to 'Democracy and School Math' Democracy \& Education, 19(2). Available from http://democracyeducationjournal. $\mathrm{org} / \mathrm{cgi} / \mathrm{viewcontent} . \mathrm{cgi}$ ?article=1036\&context=hom

Almeida, D.F. (2010). Are there viable connections between mathematics, mathematical proof and democracy? Philosophy of Mathematics Education Journal, 25. Available from http://people.exeter.ac.uk/PErnest/pome25/D.\%20 F.\%20Almeida\%20\%20Are\%20There\%20Viable\%20Connections.docx

Alrø, H., \& Johnsen-Høines, M. (2010). Critical dialogue in mathematics education In H. Alrø, O. Ravn, \& P. Valero (Eds.), Critical mathematics education: Past, present and future: Festschrift for Ole Skovsmose (pp. 11-21). Rotterdam: Sense Publishers.

Alrø, H., \& Skovsmose, O. (2002). Dialogue and learning in mathematics education: Intention, reflection, critique. Dordrecht: Kluwer Academic Publishers.

Amit, M., \& Fried, M. (2005). Authority and authority relations in mathematics education: A view from an 8th grade classroom. Educational Studies in Mathematics, 58, 145-168. http://dx.doi.org/10.1007/s10649-005-3618-2

Andrews, P. (2007). Conditions for learning: A footnote on pedagogy and didactics. Mathematics Teaching, 204, 22

Anthony, G., \& Walshaw, M. (2007). Effective pedagogy in mathematics/pangarau: Best evidence synthesis iteration [BES]. Wellington: Ministry of Education.

Bailey, S., \& Murray, D. (2009). The status of youth in Palestine. Ramallah \& Gaza: Sharek Youth Forum.

Ball, D.L., Goffney, I.M., \& Bass, H. (2005). The role of mathematics instruction in building a socially just and diverse democracy. The Mathematics Educator, 15(1), 2-6. Available from http://math.coe.uga.edu/tme/Issues/v15n1/V15N1_Ball.pdf

Bar-Al, S., \& Noymeyer, M. (1996). Mipgashim em hapsikhology [Meetings with psychology]. Even-Yehuda, Israel: Rekhs publishing.

Barner, M. (1998, September). Analyzing power relationships in collaborative groups in mathematics. Paper presented at the First International Mathematics Education and Society Conference, Nottingham. Available from http://www.nottingham. ac.uk/csme/meas/papers/barnes.html

Botas, B. (2004). Students' perceptions of teachers' pedagogical styles in higher education. Educate, 4(1), 16-30. Available from http://www.educatejournal.org/ index.php/educate/article/view/77/74

Boylan, M. (2009). Engaging with issues of emotionality in mathematics teacher education for social justice. Journal of Mathematics Teacher Education, 12(6), 427-443. http://dx.doi.org/10.1007/s10857-009-9117-0

Canadian International Development Agency. (2010). Education: Gender equality. Gatineau, Quebec: CIDA.

Chanal, J.P. Sarrazin, P.G., Guay, F., \& Boiché, J. (2009). Verbal, mathematics, and physical education self-concepts and achievements: An extension and test of the physical education self-concepts and achievements: An extension and test of the
Internal/External frame of Reference Model. Psychology of Sport and Exercise, 10, Internal/External frame of Reference Model. Psychology of Spor
$61-66$. http://dx.doi.org/10.1016/j.psychsport.2008.06.008

Cristillo, L. (2009). National study of undergraduate teaching practices in Palestine. West Bank-Gaza: United States Agency for International Development.
PMid:19878696, PMCid:2767655 Available from http://www.pdx.edu/sites/www. pdx.edu.cae/files/Cristillo.\%20Pal\%20HiEd\%20Report\%20(full).pdf
Cristillo, L. (2010). Struggling for the center: Teacher-centered vs. learner-centered practices in Palestinian higher education. In Higher Education and the Middle East, Vol. II (pp.
37-40). Washington, DC: Middle East Institute. Available from http://hawk.ethz.ch/ 37-40). Washington, DC: Middle East Institute. Available from http://hawk.ethz.ch/
serviceengine/Files/ISN/122711/ichaptersection singledocument/92876ef8-5720serviceengine/Files/ISN/122711/ichapte

Croom, L. (1997). Mathematics for all students: Access, excellence, and equity. In J. Trentacosta (Ed.), Multicultural and gender equity in the classroom: The gift of diversity (pp. 1-9). 1997 Yearbook of the National Council of Teachers of Mathematics. Reston, VA: NCTM.

Davis, M.H. (2010). Practicing democracy in the NCLB elementary classroom Unpublished master's thesis. Dominican University of California, San Rafael, California, United States.

Ellis, M. \& Malloy, C.E. (2009). Preparing teachers for democratic mathematics education. In D. Pugalee, A. Rigerson, \& A. Schinck (Eds.), Proceedings of the Mathematics Education in a Global Community. Ninth International Conference (pp. 160-164). Available from http://math.unipa.it/ grim/21_project/21_ charlotte Ellis\%20and\%20MalloyPaperEdit.pdf

Fraivillig, J.L. (2001). Strategies for advancing children's mathematical thinking. Teaching Children Mathematics, 7(8), 454-459.

Gelber, K. (2009). Academic freedom and the 'intellectual diversity' movement in Australia. Australian Journal of Human Rights, 14(2), 95-114.

Geoghegan, N., Petriwskyj, A., Bower, L., \& Geoghegan, D. (2003). Eliciting dimensions of leadership in educational leadership in early childhood education. Journal of Australian Research in Early Childhood Education, 10(1), 12-21.

Glaser, B., \& Strauss, A. (1967). The discovery of grounded theory. Chicago, IL: Aldine.

Grouws, D., \& Cebulla, K. (2000). Improving student achievement in mathematics. Geneva: International Academy of Education.

Hannaford, C. (1998). Mathematics teaching is democratic education. ZDM: The International Journal on Mathematics Education, 30(6), 181-187. http://dx.doi. org/10.1007/s11858-998-0008-0

Harwood, A.M., \& Hahn, C.L. (1990). Controversial issues in the classroom. ERIC Document Reproduction Service ED327453.

Isman, A., Altinay, Z., \& Altinay, F. (2004). Roles of the students and teachers in distance education. Turkish Online Journal of Distance Education-TOJDE, 5(4). Available from http://tojde.anadolu.edu.tr/tojde16/articles/isman.htm

Kesici, S. (2008). Teachers' opinions about building a democratic classroom. Journal of Instructional Psychology, 35(2), 192-203.

Kibler, V.E., Rush, B.L, \& Sweeney, T.J. (1985). The relationship between Adlerian course participation and stability of attitude change. Individual Psychology: The Journal of Adlerian Theory, Research \& Practice, 41(3), 354-362.

Klassen, W. (2008). Math for the diverse learner in the elementary classroom. Unpublished manuscript. University of British Columbia, Vancouver, Canada. Available from http://educationaltechnology.ca/westcast2008/files/Math\%20 for\%20Diverse\%20Learners.pdf

Kohn, A. (1997). How not to teach values? Education Digest, 62, 12-17.

Larrivee, B. (2002). The potential perils of praise in a democratic interactive classroom. Action in Teacher Education, 23(4), 77-88. http://dx.doi.org/10.1080/01626620. 2002.10463091

Lincoln, Y.S., \& Guba, E.G. (1985). Naturalistic inquiry. Beverly Hills, CA: Sage.

MacMath, S. (2008). Implementing a democratic pedagogy in the classroom: Putting Dewey into practice. Canadian Journal for New Scholars in Education, 1(1), 1-12.

Morrison, K. (2008). Democratic classrooms: Incorporating student voice and choice in teacher education courses. Unpublished document. Available from http://www. newfoundations.com/Morrison.html

Moses, R.P., \& Cobb, C.E., Jr. (2001). Radical equations: Math literacy and civil rights. Boston, MA: Beacon Press.

National Council of Teachers of Mathematics. (1990). Principles and standards for school mathematics. Reston, VA: NCTM.

Olaye, A.A. (2008). Andragogical approach for sustainable democracy: A sociolinguistic review. Ethiopian Journal of Education and Sciences, 3(2), 97-106. http://dx.doi. org/10.4314/ejesc.v3i2.42002

Poduska, K. (1996). To give my students wings. In L.E. Beyer (Ed.), Creating democratic classrooms: The struggle to integrate theory and practice (pp. 106-126). New classrooms: The struggle to integr
York, NY: Teachers College Press.

Porter, T. (1995). Trust in numbers: The pursuit of objectivity in science and public life. Princeton, NJ: Princeton University Press.

Povey, H. (1997). Beginning mathematics teachers' ways of knowing: The link with working for emancipatory change. Curriculum Studies, 5(3), 329-343. http:// dx.doi.org/10.1080/14681369700200016

Povey, H. (2010). Teaching for equity, teaching for mathematical engagement. Philosophy of Mathematics Education Journal, 25. Available from http://people. exeter.ac.uk/PErnest/pome25/Hilary\%20Povey\%20\%20Teaching\%20for\%20 Equity.doc

Ramos, M.C. (1989). Some ethical implications of qualitative research. Research in Nursing \& Health, 12, 57-63. http://dx.doi.org/10.1002/nur.4770120109

Schifter, D. (2001). Learning to see the invisible: What skills and knowledge are needed to engage with students' mathematical ideas? In T. Wood, B.S. Nelson, \& J. Warfield (Eds.), Beyond classical pedagogy: Teaching elementary school mathematics (pp. 109-134). Mahwah, NJ: Lawrence Erlbaum.

Sgroi, L.A. (1995). Assessing young children's mathematical understandings. Teaching Children Mathematics, 1(5), 275-277.

Shulman, L.S. (1987). Knowledge and teaching: Foundations of the new reform. Harvard Educational Review, 57(1), 1-22. Available from http://her.hepg.org/ content/j463w79r56455411/fulltext.pdf 
Skemp, R.R. (1979). Goals of learning and qualities of understanding. Mathematics Teaching, 88, 44-49.

Skovsmose, O. (1998). Linking mathematics education and democracy: Citizenship, mathematical archaeology, mathemacy and deliberative interaction. ZDM: The International Journal on Mathematics Education, 98(6), 195-203. http://dx.doi. org/10.1007/s11858-998-0010-6

Skovsmose, O., \& Valero, P. (2005). Mathematics education and social justice: Facing the paradoxes of the informational society. Utbildning \& Demokrati, 14(2), 57-71.

Staples, M., \& Bartlo, J. (2010). Justification as a learning practice: Its purposes in middle grades mathematics classrooms. CRME Publications. Available from http:// digitalcommons.uconn.edu/cgi/viewcontent.cgi?article=1002\& context=merg docs

Strauss, A \& Corbin, J. (1998). Basics of qualitative research: Techniques and procedures for developing grounded theory. ( 2 nd edn.). Thousand Oaks, CA: Sage.

Susuwele-Banda, W.J. (2005). Classroom assessment in Malawi: Teachers' perceptions and practices in mathematics. Unpublished doctoral dissertation. The Virginia Polytechnic Institute and State University, Blacksburg, Virginia, United States.

Trouilloud, D., Sarrazin, P., Martinek, T., \& Guillet, E. (2002). The influence of teacher expectations on student's achievement in physical education classes: Pygmalion revisited. European Journal of Social Psychology, 32(5), 591-607. http://dx.doi. org/10.1002/ejsp.109

United States Agency for International Development. (2008). Education from a gender equality perspective. Washington, DC: USAID Office of Women in Development.
Vithal, R. (1999). Democracy and authority: A complementarity in mathematics education? ZDM: The International Journal on Mathematics Education, 98(6), 27-36. http://dx.doi.org/10.1007/s11858-999-0005-y

Vithal, R. (2000a). In search of a pedagogy of conflict and dialogue for mathematics education. Unpublished doctoral dissertation. Aalborg University, Aalborg, Denmark.

Vithal, R. (2000b). Re-searching mathematics education from a critical perspective In J.F. Matos, \& M. Santos (Eds.), Proceedings of the Second International Mathematics Education and Society Conference (pp. 87-116). Lisbon: CIEFC Universidade de Lisboa.

Wagner, D., \& Herbel-Eisenmann, B. (2011, July). Trying to be democratic in mathematics class. Paper presented at the 63rd Conference of the Commission for the Study and Improvement of Mathematics Teaching, Barcelona, Spain.

Wilson, M.R., \& Lloyd, G.M. (1996, April). Sharing mathematical authority: New roles for teachers. Paper presented at the Research Pre-session of the 74th
Annual Meeting of the National Council of Teachers of Mathematics, San Diego, California, United States.

World Bank. (2008). The road not traveled: Education reform in the Middle East and North Africa. Washington, DC: The World Bank. Available from http:// siteresources.worldbank.org/INTMENA/Resources/EDU_Flagship_Full_ENG.pdf

Zhang, X. (2005). Analyzing the power relationships in mathematics classroom Journal of the Korea Society of Mathematical Education Series, 9(2), 115-124. 